\title{
Creative Thinking Processes of Vocational Students With High Learning Motivation In Mathematic Problem Posing
}

\author{
Maya Kristina Ningsih \\ Departmen of Mathematic Education \\ Sebelas Maret University \\ Surakarta, Indonesia \\ may_kris78@yahoo.com
}

\author{
Imam Sujadi \\ Departmen of Mathematic Education \\ Sebelas Maret University \\ Surakarta, Indonesia \\ imamsujadi@ymail.com
}

\author{
Sri Subanti \\ Departmen of Mathematic Education \\ Sebelas Maret University \\ Surakarta, Indonesia \\ sri_subanti@yahoo.co.id
}

\begin{abstract}
In this study described the process of creative thinking vocational students with high learning motivation in mathematic problem posing. This research is qualitative research. The subjects were 2 students class XI AP-4 SMK Negeri 2 Madiun in the 2016/2017 academic year, who have high learning motivation. Sample was taken by purposive sampling. A test of mathematic problems posing (MPP test) was then given to the selected subjects to identify their creative thinking process in mathematic problems posing. Periodical triangulation was applied to check data validity. Data analysis began by collecting data of MPP test and interview with the subjects, followed by describing students' mathematic problems posing into short description. The result of this study showed that: (1) preparation; students read MPP test silently, observed the instruction and information on MPP test carefully, observed what was known and asked in the test by reading once, and explained what he has understood from what was asked fluently and correctly; (2) incubation; Students hesitated for a moment as a way to find and set a strategy to answer the items in the MPP test; (3) illumination; students determined the attribute and some other things necessary to pose the mathematic problems, and verbally explained the problems while stooping head, wrote the the mathematic problems on the answer sheet, and revised the answer when they made mistakes in posing the problems; (4) verification; students read and revised the mathematic problem that has been posed, verbally explained procedures of solving the posed mathematic problem on the answer sheet, and revised and corrected the problem and solution they have proposed.
\end{abstract}

Keywords-creative thinking processes; high learning motivation; mathematic problem posing;

\section{INTRODUCTION}

Advances in science and technology in a more complex and demanding world require students to have critical, systematic, logical, and creative thinking and have ability to effectively cooperate with other people. These abilities can be developed in the learning of mathematics. In the same way of Ministerial Regulation No. 22 of 2006 on content standards for elementary and secondary education units, stating that mathematics should be given to all learners ranging from elementary schools to equip learners with logical thinking analytical, systematic, critical and creative thinking skills And the ability to work together. Two some important points the objectives of mathematics learning are fostering critical and creative thinking skills. This means, the ability of creative thinking needs to be developed in the learning of mathematics.

The ability to think creatively can be developed through activities in the learning activities of mathematics that can encourage or create student creativity. Creativity can be viewed as a product of creative thinking process. Creative thinking a mental activity that someone uses to create new ideas [1]. Further, [2] mentioned creative thinking as a combination of logical thinking and divergent thinking processes which based on intuition and conscience.

One of the ways to encourage students to think creatively in the learning of mathematics is through problem posing. Problem posing has a strategis position in the learning of mathematics, as it is the most important issue in the discipline and logical thinking of mathematics. The problem posing is an essential part of the student's mathematical experience. The 2013 Curriculum requires students to actively ask questions, to find and analyze information and to put forward ideas and opinions more than the teachers do. The American curriculum of mathematics education, Curriculum and Evaluation Standards for School Mathematics [3] suggests that students are given more opportunities to investigate and formulate questions out of problem situations. The activities of problems posing can help students to develop their image and success towards mathematics. Problem posing is one form of students' communication in the learning of mathematics. Problem posing correlates with ability to solve problems, because the improvement of problem posing ability also increases the problem solving ability.

Creativity is a product of creative thinking, in which an individual implements a thinking process called creative thinking process. This process combines the logical and divergent thinking processes. Divergent thinking is a process to search for ideas to find solutions to problems, whereas logical thinking is used to verify these ideas to become a creative solution. The creative thinking process in posing mathematic problems consists of several stages. This research used the 
creative thinking process suggested by Wallas [4], namely (1) preparation; (2) incubation; (3) illumination; (4) verification.

A research on mathematic creativity has been conducted by Haylock [5]; one of the issues is about the ability of problems posing as a creative ability. The research viewed more on the product of problems posing using criteria of creativity, namely fluency, flexibility and originality, not on the creative process which emphasized on the students' cognitive aspect when problems posing, whether or not it fulfils criteria of creative thinking. Leung's research to fifth graders of an elementary school in Taiwan showed that it is flexibility and context which built general characteristics of verbal creative thinking and problems posing, while flexibility was not the general characteristic of both, but rather, the characteristics in arithmetical problem posing. The research gave empirical evidence about the relation of creative thinking and mathematic problem posing.

Balka [6] in his research asked students to pose mathematic problems which could be solved based on the information provided by a collection of situations in the real world. It was concluded that some components of creative thinking were also found in the process of creative thinking. For example, the fluency in problems posing refered to the number of different categories of the constructed problems and originality refered to irregularity of the posed problems.

A research by Siswono [7] to the second grade students of Public Islamic Junior High School (MTs Negeri) Rungkut Surabaya revealed that students with different ability levels (high, average, and low) showed different thinking patterns in posing problems. The high level students were more careful and well-planned, whereas the average and low level students were less, or even not, careful and well-planned. However, in general students already had knowledge on how to pose problems based on the required tasks given by teacher. Students tended to make question/problems with similar patterns to be solved, and ones based on the required tasks. This finding did not seem to reveal the creative thinking in making questions, which may be caused by the fact that the task only consisted of written text/instruction, so it did not invite students' imagination to think creatively.

Learning which involves problem posing can develop students' creative thinking, because in this kind of learning, students have to think out of the box. They will use their thinking capacity to pose problems based on situations or available information. When asked to pose problems/questions out of a certain situation, students will have to read carefully, pay attention to the given quantitative information, and finally try to pose questions based on the situation.

A person's creativity to produce new ideas and create useful new innovations is influenced by a number of important factors. These factors can be from either his own self or his environment. These factors include cognitive aspect, motivation, personal characteristics and environment [7]. This is also reinforced by the opinion of Goleman who states that intellectual intelligence (IQ) only contributes $20 \%$ for success while $80 \%$ is a contribution of other power factors, such as emotional intelligence or Emotional Quetient (EQ) is the ability to motivate yourself, overcome frustration, control the urge of heart, set the mood (mood), empathy and ability to work together.

Learning motivation is student's internal and external drive when learning, in order to yield changes in behavior [8]. Students who have high motivation will take serious effort in learning so that they will become more creative and are able to improve their achievement. Lack of motivation, direction and guidance from teachers leads to low student activity in raising issues.

To identify the creative thinking process of students who have high learning motivation when they have to pose mathematic problems, a study is necessary to conduct. In relation to the above background, the purposes of this research are to investigate the creative thinking process of students of Class XI AP-4 of Public Vocational High School (SMK) Negeri 2 Madiun, who have high learning motivation in proposing mathematic problems, which includes stages of preparation, incubation, illumination, and verification.

The theoretical benefit that can be obtained from this research is that the research can theoretically contribute on the relation between students' creative thinking process and learning motivation in mathematic problems posing. Some practical benefits are: (1) for students, the research can be a source of information to recognize and comprehend their creative thinking process when posing mathematic problems; (2) for teachers, the research can guide them to identify students' creative process when posing mathematic problems, viewed from learning motivation.

\section{RESEARCH METHODS}

This research was a qualitative research aiming to describe the students'with high learning motivation creative thinking process in mathematic problems posing. The research was conducted in SMK Negeri 2 Madiun which is located on $\mathrm{Jl}$. Letjen Harjono no. 18 Madiun, East Java. The school was chosen because of the consideration that in SMK Negeri 2 Madiun there has not been any research about the students' creative thinking process in posing mathematic problems viewed from learning motivation.

The subject of the research was the students of Class XI AP4 SMK Negeri 2 Madiun in the academic year 2016/2017. The subjects were selected by purposive sampling, considering that the students of Class XI were likely to be able to communicate their ideas, orally or written, quite well, so that it is possible to explore the students' creative thinking process, and the purposively selected students were assumed to have a variety of creative thinking process in mathematic problems posing. Based on the score of learning motivation questionnaire, six students were selected, three with high learning motivation, and three with average learning motivation.

Instruments in this study are divided into 2 parts namely the main instrument and auxiliary instruments. The main instrument in this study is the interviewer (researcher himself). Auxiliary instruments in the form of the first auxiliary instrument is a questionnaire of learning motivation to 
determine the level of student's learning motivation, the second auxiliary instrument is the test of mathematical problems posing of linear program material, and the third aids instrument in the form of interview guidance. As for the test instrument of mathematical problem posing (MPP test) is as following table:

TABLE 1 Instrumen Of Mathematical Problem Posing (MPP TEST)

\begin{tabular}{|c|c|}
\hline MPP test & Instrumen \\
\hline $\begin{array}{l}\text { MPP } \\
\text { test-1 }\end{array}$ & $\begin{array}{l}\text { A bicycle shop provides two types of bicycles namely } \\
\text { BMX bikes and federal bikes, each costing Rp } 400,000 \text { and } \\
\text { Rp } 500,000 \text {. The store capacity is not more than } 50 \\
\text { bicycles. The profit from BMX and federal bike sales is Rp } \\
40,000 \text { and Rp } 60,000 \text { respectively. Capital owned by the } \\
\text { shop owner for Rp } 23,000,000 \text {. } \\
\text { 1. From the information make a question or statement at } \\
\text { least } 3 \text { ! } \\
\text { 2. Choose at least } 1 \text { question from your question created, } \\
\text { then do it! }\end{array}$ \\
\hline $\begin{array}{l}\text { MPP } \\
\text { test-2 }\end{array}$ & $\begin{array}{l}\text { A type of bread requires } 150 \text { grams of flour and } 50 \text { grams } \\
\text { of butter while the other type requires } 75 \text { grams of flour } \\
\text { and } 75 \text { grams of butter. Available materials are } 9 \mathrm{~kg} \text { of } \\
\text { flour and } 6 \mathrm{~kg} \text { of butter. } \\
\text { 1. From the information make a question or statement } \\
\text { at } \\
\text { least } 3 \text { ! } \\
\text { created, } \\
\text { then do it! }\end{array}$ \\
\hline
\end{tabular}

In collecting data, the research used a test of mathematic problem posing (MPP test) and interview conducted by researchers as the main instrument. Interviews were conducted to explore the subject thinking process in the application of mathematical problems of linear program materials, with the following steps: (1) selecting 3 students with high learning motivation; (2) giving the first test of mathematic problem posing (MPP-1) to the selected subjects, and asking questions to students related to their creative thinking process. Students' expressions and answers were recorded using the recorder of a smartphone; and (3) selecting 2 students as research subjects, under consideration that they could provide complete data about creative thinking process in mathematic problems posing, both orally and written.

Trustworthiness or validity of data was checked using periodic triangulation. The four students as research subjects were given MPP-2 to observe data validity on the first data collection. The data obtained from MPP-1 and MPP-2 were then compared to check its validity. The data were analyzed using qualitative technique of data analysis, which involved: (1) collecting data of MPP and interview to research subjects, reducing data; (2) constructing the description of students' problem posing in the form of short description and table; and (3) drawing conclusions of students' creative thinking process based on learning motivation of mathematics. To simplify data analysis and discussion, the 2 selected students were named as follows: MBT-1 and MBT-2.

\section{RESULTS AND DISCUSSION}

The research observation obtained data of recordings on students' creative thinking process for each level of learning motivation, which was the most comprehensive and could support the description of students' creative thinking in posing problems. Afterwards, an in-depth analysis was done to the recordings according to the steps by Wallas, namely the preparation, incubation, illumination, and verification. The analysis of the first recording was then followed by the analysis of the second one. This was done to check data validity by comparing both of the recordings. Data were reduced when there were different kinds of data between the two. From the analysis, the research can explain the result of students' creative thinking process according to each of their level of mathematics learning motivation.

From the analysis to each of the research subjects based on Wallas' steps, the research obtained valid data of the creative thinking process of students of Class XI AP-4 SMK Negeri 2 Madiun in the academic year 2016/2017. The valid data of creative thinking process of MBT students are presented in the following table.

TABLE 2 VALid Data Of CREATIVE Thinking PROCESS IN Mathematic PROBLEMS Posing For MBT STUDENTS

\begin{tabular}{|c|c|c|}
\hline \multirow[t]{2}{*}{ Wallas' steps } & \multicolumn{2}{|c|}{$\begin{array}{c}\text { Valid Data of Creative Thinking Process in } \\
\text { Mathematic Problems Posing }\end{array}$} \\
\hline & MTB 1 student & MTB 2 student \\
\hline 1) Preparation & 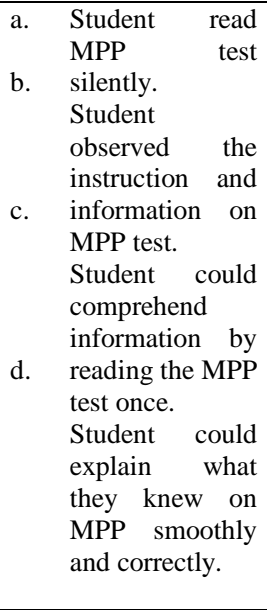 & $\begin{array}{ll}\text { a. } & \begin{array}{l}\text { Student read } \\
\text { MPP test } \\
\text { b. }\end{array} \\
\text { silently. } \\
\text { Student } \\
\text { observed the } \\
\text { instruction and } \\
\text { c. } \\
\text { information on } \\
\text { MPP test } \\
\text { carefully. } \\
\text { Student could } \\
\text { comprehend } \\
\text { d. } \begin{array}{l}\text { information by } \\
\text { reading the }\end{array} \\
\text { MPP test once. } \\
\text { Student could } \\
\text { explain what } \\
\text { they knew on } \\
\text { MPP smoothly } \\
\text { and correctly. }\end{array}$ \\
\hline 2) Incubation & 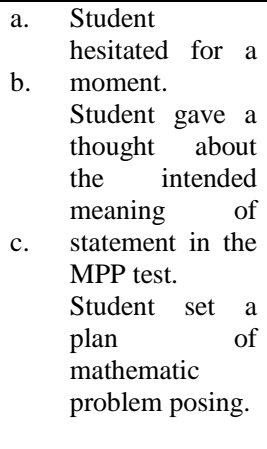 & $\begin{array}{ll}\text { a. } & \begin{array}{l}\text { Student } \\
\text { hesitated for a } \\
\text { b. }\end{array} \\
\text { moment. } \\
\text { Student gave a } \\
\text { thought about } \\
\text { the intended } \\
\text { meaning of } \\
\text { c. } \text { statement in the } \\
\text { MPP test. } \\
\text { Student set a } \\
\text { plan of } \\
\text { mathematic } \\
\text { problem posing. } \\
\text { composedly. }\end{array}$ \\
\hline
\end{tabular}


TABLE 2 Valid Data Of CReative Thinking Process IN Mathematic Problems Posing For Mbt STUDENTS

\begin{tabular}{|c|c|c|}
\hline 3) Illumination & 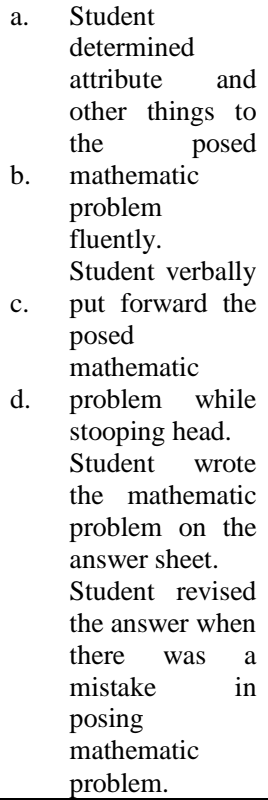 & 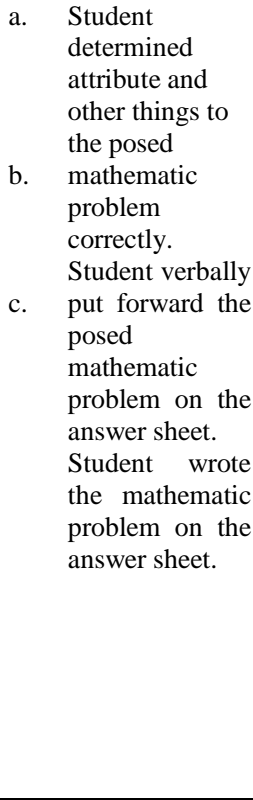 \\
\hline 4) Verification & $\begin{array}{l}\text { a. Student revised } \\
\text { the mathematic } \\
\text { problem that has } \\
\text { been posed. } \\
\text { Student } \\
\text { explained } \\
\text { procedures of } \\
\text { solving the } \\
\text { posed } \\
\text { mathematic } \\
\text { problem } \\
\text { Student wrote } \\
\text { the solution of } \\
\text { the mathematic } \\
\text { problem on the } \\
\text { answer sheet. } \\
\text { Student revised } \\
\text { and corrected } \\
\text { the problem and } \\
\text { solution. }\end{array}$ & 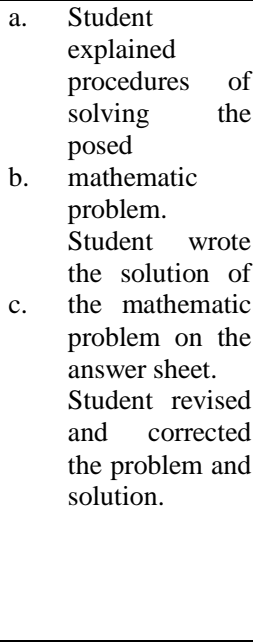 \\
\hline
\end{tabular}

Based on Table 2, the conclusion to the creative thinking process and mathematic problem posing of the MBT students based on Wallas' steps is presented in the following Table 3:

TABLE 3 VALID DATA OF MBt STUDENTS' CREATIVE THINKING Process In MATHEMATIC PROBLEMS POSING

\begin{tabular}{|c|c|}
\hline Wallas' steps & $\begin{array}{l}\text { Valid Data of Students' Creative Thinking } \\
\text { Process in Mathematic Problems Posing }\end{array}$ \\
\hline 1) Preparation & $\begin{array}{ll}\text { a. } & \text { Students read MPP test silently. } \\
\text { b. } & \text { Students observed the instruction and } \\
\text { information on MPP test carefully } \\
\text { c. }\end{array}$ \\
\hline
\end{tabular}

TABle 3 Valid Data Of Mbt Students' Creative Thinking Process In MATHEMATIC PROBLEMS Posing

\begin{tabular}{|l|ll|}
\hline 2) Incubation & $\begin{array}{l}\text { a. } \\
\text { b. }\end{array}$ & $\begin{array}{l}\text { Students hesitated for a moment. } \\
\text { Students gave a thought about the intended } \\
\text { meaning of statement in the MPP test. }\end{array}$ \\
c. & $\begin{array}{l}\text { Students could set a plan of posing mathematic } \\
\text { problem composedly. }\end{array}$ \\
\hline 3) Illumination & a. & $\begin{array}{l}\text { Students determined attribute and other things } \\
\text { necessary to the posed mathematic problem } \\
\text { fluently. }\end{array}$ \\
b. & $\begin{array}{l}\text { Students verbally put forward the posed } \\
\text { mathematic problem while once in a while } \\
\text { stooping head. }\end{array}$ \\
c. & $\begin{array}{l}\text { Students wrote the mathematic problem on the } \\
\text { answer sheet. } \\
\text { Students revised the answer when there was a } \\
\text { mistake in posing mathematic problem. }\end{array}$ \\
\hline 4) Verification & a. $\quad \begin{array}{l}\text { Students read and revised the mathematic } \\
\text { problem that has been posed. }\end{array}$ \\
b. & $\begin{array}{l}\text { Students explained procedures of solving the } \\
\text { posed mathematic problem. }\end{array}$ \\
c. & $\begin{array}{l}\text { Students wrote the solution of the mathematic } \\
\text { problem on the answer sheet. } \\
\text { Students revised and corrected the problem and } \\
\text { solution. }\end{array}$ \\
\hline
\end{tabular}

\section{CONCLUSION}

Based on the data analysis to the 4 research subjects, some conclusions are drawn on the creative thinking process in posing mathematic problems of students of Class XI AP-4 SMK Negeri 2 Madiun. First, MBT students (those having high learning motivation) followed these steps: (a) preparation; students read MPP test silently, observed the instruction and information on MPP test carefully, observed what was known and asked in the test by reading once, and explained what he has understood from what was asked fluently and correctly; (b) incubation; Students hesitated for a moment as a way to find and set a strategy to answer the items in the MPP test; (c) illumination; students determined the attribute and some other things necessary to pose the mathematic problems, and verbally explained the problems while stooping head, wrote the mathematic problems on the answer sheet, and revised the answer when they made mistakes in posing the problems; (d) verification; students read and revised the mathematic problem that has been posed, verbally explained procedures of solving the posed mathematic problem on the answer sheet, and revised and corrected the problem and solution they have proposed.

\section{REFERENCES}

[1] Siswono, Tatag Y.E, Penjenjangan Kemampuan Berpikir Kreatif dan Identifikasi Tahap Berpikir Kreatif Siswa dalam Memecahkan dan Megajukan Masalah Matematika, "Dissertation" Surabaya: Graduate School, Universitas Negeri Surabaya (UNESA), Unpublished, 2007.

[2] Pehkonen, E, The State-of-Art in Mathematical Creativity, "Zentralblatt fur Didaktik der Mathematik (ZDM)-The International Journal on Mathematics Education", [Online], Vol 97(3), 1997, 63-67, http://www.emis.de/journal/ZDM/zdm973a3.pdf, [10 Maret 2016].

[3] Siswono, Tatag Y.E, Metode Pemberian Tugas Pengajuan Soal (Problem Posing) dalam pembelajaran Matematika Pokok Bahasan Perbandingan di 
Didaktik der Mathematik (ZDM)-The International Journal on Mathematics Education", [Online], Vol 97(3), 1997, 75-80, http://www.emis.de/journals/ZDM/zdm9733.pdf. [10 Maret 2016].

[7] Komarudin, Proses Berpikir Kreatif Siswa SMP dalam Pengajuan Masalah Matematika ditinjau dari Gaya Kognitif Siswa, "Thesis", Surakarta: UNS Graduate School, 2014, Unpublised.

[8] Uno, Hamzah B, "Teori Motivasi dan Pengukurannya", Jakarta: PT Bumi Aksara, 2016.

[6] Silver, E, A, Fostering Creativity through Instruction Rich in Mathematical Problem Solving and Problem Posing, "Zentralblatt fur 